\title{
Leading for quality: Questions about quality and leadership in Australia
}

\begin{abstract}
This paper is situated in the context of recent policies for teacher quality in Australia. Discourses on quality have crossed many domains of public policy, including education. A feature of these discourses has been an emphasis on improving teacher quality and raising professional standards. The paper uses Critical Discourse Analysis to explore the implications of quality discourses for educational leadership. In so doing, it analyses how recent educational policies construct discourses on quality and professional standards, discourses which position educational leaders in particular, often contradictory, ways. Such positionings offer different ways of understanding leaders and how best they might lead for quality. The paper concludes by raising questions about quality and leadership, questions that highlight the need to rethink educational leadership within a quality policy framework.
\end{abstract}

\section{Introduction}

Discourses on quality have been a feature of education policy for the last twenty years (Vidovich and Porter 1999). Such discourses have impacted at a global level (cf. Henry, Lingard, Rizvi and Taylor 2001, for a discussion of the impact of the global discourse of quality on the OECD), and on individual nations. For example, Apple (2004) has discussed the impact of quality discourses in the USA; Whitty (2002) examines their impact on teacher professionalism in the UK; and Sachs (2003) analyses discourses on teacher quality in Australia. Further, policy discourses have linked quality to strong and effective educational leadership in a global phenomenon evidenced in the US (Olson 2000), British (Department for Education and Employment 2001) and New Zealand (Ministry of Education 1998) 
education systems among others.

In Australia, the significance of educational leaders both to quality student outcomes and to successful innovation in educational practices has been highlighted by government policies at both the national and state levels ${ }^{1}$ (cf. Education Queensland 1999; Department of Employment Education Training and Youth Affairs 2000; Department of Education Science and Training 2003a). These policies describe quality leaders as being essential to quality schooling because the quality of the system depends on the quality of educational leadership in schools (cf. Education Queensland 1999; Department of Employment Education Training and Youth Affairs 2000; Ramsey 2000). Consequently, initiatives have been introduced to support and strengthen quality educational leadership. Such initiatives include the introduction of a National Institute of Quality Teaching and School Leadership (NIQTSL) (Department of Education Science and Training 2003b), a national Quality Leaders program (Department of Employment Education Training and Youth Affairs 2000) and a Strategic Leaders Program in the State of Queensland.

This paper looks critically at policy discourses on quality and educational leadership. It examines two contemporary Australian policies that focus on the quality of schools, teachers and leaders, Teachers for the 21st Century (Department of Employment Education Training and Youth Affairs 2000) and Australia's Teachers: Australia's Future - Advancing Innovation, Science, Technology and Mathematics (Department of Education Science and Training 2003a). Drawing on Critical Discourse Theory, the paper analyses how these policies construct discourses on quality and professional standards, discourses which position educational leaders in particular, often contradictory, ways. Such positionings offer different 
ways of understanding leaders and how best they might lead for quality. The paper concludes by raising questions about quality and leadership, questions that highlight the need to rethink educational leadership within a quality policy framework.

\section{Looking at Policy and Leadership}

The following analysis of the relationship between education policy and leadership is based on an understanding that leadership is not achieved in a social vacuum but can be understood only in the context of its wider cultural setting (see also Ball 1994; Gunter 2001; Bell and Rowley 2002; Collard 2004; Spillane, Halverson and Diamond 2004). That is, the school leadership-society relation defines what it is to be an educational leader (Grace 2000). Further, the realisation of educational leadership is always set within a framework of possibilities and constraints derived from the cultural, political and economic contexts of education, and from education policies framed within these contexts. Particular policy frameworks articulate particular leadership roles and responsibilities and exclude others. For example, recent changes in education policy in the UK have led to increased responsibilities and accountabilities for head teachers who report a resultant change in leadership style (Bell and Rowley 2002).

An approach that places leadership in its wider cultural context is one that recognises that people, including educational leaders, policy-makers and governors, live and act within a textually-mediated social world (Smith 1990). As Luke (2002) notes, advanced capitalist societies are characterised by new forms of social life that turn on text and discourse. Such societies are enabled by discourse saturated environments, or semiotic economies, where 
'text, language and discourse have become the principal modes of social relations, civic and political life, economic behaviour and activity, where means of production and modes of information become intertwined in analytically complex ways' (Luke 2002, p. 98). Indeed, discursive effects saturate all other moments in the social process, 'internalis[ing] in some sense everything that occurs as other moments' (Harvey 1996, p. 80). Therefore, while it is important not to privilege the discursive over other moments in social life, it is necessary to recognise that an analysis of the discursive moment is essential to furthering understandings of social life. That is, an analysis of the discursive constructions of leadership in educational policies is essential to furthering understandings of thinking about, and doing, leadership. Such an analysis recognises that the role and sense of school leaders are being reworked and redefined in struggles over language, policy and practice (Peters, Marshall and Fitzsimons 2000).

In this paper, educational policy discourses are considered to be forms of social practice, subject to particular rules and transformations through which particular representations of truth and self are constructed within particular power relations (Ball 1993; Schram 1993; Allan 1998). As such, policy discourses work to define not only what can be said and thought, but also who can speak, where, when and with what authority (Ball 1993). Policy discourses on leadership, therefore, define both what quality leadership can and should be, as well as who can and should speak with authority on leadership. Similarly, discourses on leaders both construct particular professional identities, or versions of being a good leader, as well as providing possibilities for leaders to create alternative identities or styles, ways of representing themselves (Fairclough 2003). Consequently, the professional identity of educational leaders is shaped and constrained within a discursive field constructed through 
many discourses, including discourses on policy. These discourses form discursive chains or threads in overlapping clusters that work to naturalise, or reify, common sense understandings of educational leaders, privileging a decisive definition of leadership that is generated as meanings are negotiated and contested through particular representations, identities and power relations within the discourse. That is, discourses construct a hegemonic equilibrium that constitutes subjectivities through discursive practices in a complex process of claims and counter claims, of contestation and negotiation, and in the making of discursive links across diverse sites, including that of education policy.

While recent work in educational leadership studies is concerned with the centrality of policy, such work often is concerned with amassing empirical knowledge, rather than interrogating understandings of leadership in terms of how leaders' identities and practices are shaped and constrained. One example of such interrogative research can be found in the work of Ribbins and Gunter (2002) who believe that studies of leadership should focus on leading (what leaders do in specific circumstances) and leaders (what leaders are, why and by whom they are shaped into what they are and how they become leaders). Spillane, Halverson, \& Diamond (2004) note the lack of in-depth investigations into the how of leadership, and identify the need for investigations into the interrelationships between the individual agency of leaders and the role of macro-structures, such as education policies, in shaping what leaders do. Similarly, Thomson (2003) has called for work that will lead to a better understanding of how the practices of educational leaders are produced and shaped. Such a research focus is one in which little work has been completed (Ball 1994; Apple 2001; Thomson 2003; Thomas 2004). This paper contributes to work in this area, drawing on critical discourse theory to analyse policy discourses on leadership and quality. In so doing, it 
furthers understandings both of the interrelationships between leadership and policy, and of how these interrelationships might shape and constrain leadership practices in the quality policy context.

\section{The Australian Quality Policy Context}

The following brief description of the Australian quality policy context recognises the need for a critical discourse analysis of policy texts to place the policy problem, that is the quality of teachers and schooling, in the context that frames the text/s under analysis (Thomas 2005). In Australia, several state and national education policies during the 1980s reflected concerns about the quality and relevance of education (cf. Quality of Education Review Committee 1985; Board of Teacher Registration 1987), emphasising improving the quality of educational outcomes in selected target areas and the notion of equity. However, this emphasis changed with the release of a ministerial statement in which quality was assessed not in terms of equity but in terms of the process of national microeconomic reform (Dawkins 1988).

Subsequent policies and reports (cf. Schools Council 1990; National Project on the Quality of Teaching and Learning 1992; Senate Employment Education and Training References Committee 1998; Commonwealth of Australia 2001) reinforced this theme, constructing policy discourses on quality that shifted from discourses of equity to discourses of economy, and depicted education as the 'handmaiden to the economy' (Henry et al. 2001, p.62). At the same time, policy discourses on quality shifted also to a focus on teachers and educational leaders, as improving the quality of teaching was seen to be central to the quality of schools and to the maximisation of their potential (cf. Department of 
Employment Education Training and Youth Affairs 2000; Ramsey 2000; Commonwealth of Australia 2001; Department of Education Science and Training 2003a). A fuller description of the Australian quality policy context can be found in (Thomas, 2006). The following section analyses the discursive construction of quality and of leadership in two of these recent policies on quality in Australian schooling. The policies are Teachers for the 21st Century: Making the Difference (Department of Employment Education Training and Youth Affairs 2000), hereafter Teachers for the 21st Century, and Australia's Teachers: Australia's Future - Advancing Innovation, Science, Technology and Mathematics (Department of Education Science and Training 2003a), hereafter Australia's Teachers: Australia's Future.

\section{Leadership in Two Australian Policies}

It was noted earlier that discourses on education policy and on leadership are sites of struggles and negotiations over the construction of competing and contradictory educational realities and identities. Critical Discourse Analysis (CDA) is a valuable tool for tracing both policy discourses on quality and on leadership, and the ways in which identities are constructed within and through such discourses (Taylor 2004; Thomas 2005). CDA contributes to understandings of struggles over identity by describing how social groups are represented as well as identifying unrealised potentials (Chouliaraki and Fairclough 1999). Further, CDA is concerned with 'the destabilisation of "authoritative” discourse' (Apple 1989, p. 131) as it investigates 'how power, identity and social relations are negotiated, are legitimated, and are contested toward political ends' (Apple 1996, p. 130). As such, CDA is a vehicle for public accountability and critique (Maclure 1994). 
The focus of a critical discourse analysis is on how a version of reality is presented, and accepted, as natural and common sense. The following analysis examines the textual features of repetition, modality, and presupposition as they work to construct commonsense realities about quality schooling in policy texts. Fairclough (2001) notes that repetition constitutes 'a particular way of dividing up some aspect of reality which is built upon a particular ideological representation of that reality' (p. 96). That is, repetition indicates a reality that is discursively constructed, a reality that works to privilege certain meanings over others as common sense and uncontestable and to establish an authoritative voice within the discourse. Modality refers to claims to authority on the part of the writer/s, claims that are expressed through judgements of desirability or validity (Higgins 1991). An analysis of modality provides evidence of assumptions about available sets of representations of reality, producing 'shared truths aligning readers or listeners with some statements and distancing them from others' (Kress and van Leeuwen 1996, p. 160). That is, meanings constructed in a text depend greatly on guesses and assumptions, or presuppositions, made by the reader (Fairclough 2003). Presuppositions are sometimes difficult for people to identify, and, if they wish, to reject (Fairclough 1989). The result is an ambiguity that can obscure agency, and hence causality and responsibility. Together, these textual features work to establish commonsense meanings on quality in Australian schools. The following analysis examines the use of these features in two educational policy documents in order to trace the discursive constructions of quality and leadership in recent Australian education policies.

\section{Teachers for the 21st Century}


Released in 2000, Teachers for the 21st Century established quality as its focus as it reiterated the link between quality schooling and national productivity. This focus was identified in the introduction, which noted that 'education of the highest quality is the foundation of all our futures. It is education which empowers us to rise to the challenges of social, cultural, economic and technological change that we confront today' (p. 3). The introduction further stated that 'education of the highest quality requires teachers of the highest quality' (Department of Employment Education Training and Youth Affairs 2000, p. 3). Teachers for the 21st Century outlined a program designed to improve teacher quality and to increase the effectiveness of schools. The description of the program was repeated word for word three times throughout the report: in the introduction by the then Federal Minister for Education, in the Executive Summary, and in the body of the report when outlining the central purpose of the program.

The program was described as follows:

Teachers for the $21^{\text {st }}$ Century will improve teacher quality and increase the number of highly effective Australian schools in order to maximise student learning outcomes. It will do so by:

- lifting the quality of teaching through targeted professional development and enhancing professional standards;

- developing the skills of school leaders;

- supporting quality school management; and

- recognising and rewarding quality schools, school leaders and teachers.

(Department of Employment Education Training and Youth Affairs, 2000, pp. 3, 5, 13). 
As noted earlier such repetition worked to establish a commonsense discourse of quality schooling and teachers. The use of repetition in Teachers for the 21st Century constructed a deficit discourse of teachers, leaders and schools. This discourse painted a picture of low educational standards in Australian schools and repeatedly stressed the need to raise these standards (Department of Employment Education Training and Youth Affairs 2000, p. 12). The cause of these low standards was identified as being the quality of the teaching profession. No evidence for this cause was given in the report, although the report noted that 'there has been growing concern over the status and quality of the teaching profession' (Department of Employment Education Training and Youth Affairs 2000, p. 11). Improving teacher quality was central to the program outlined in the report, which identified strategies to improve teacher quality by 'lifting the skills of practising teachers in the key priority areas' (Department of Employment Education Training and Youth Affairs, 2000, p. 5) ; 'enhancing the skills and understandings of teachers' (p. 5); and 'promoting the value and development of teaching standards and related certification' (p. 12). Indeed the need to raise professional standards through the development of standards and certification was stated repeatedly throughout the policy.

The policy defined standards as 'a means of improving the quality of teaching and enhancing the professional standing of teachers' (Department of Employment Education Training and Youth Affairs 2000, p. 17). Teachers were required to work together within their school communities to identify goals, define standards and expectations, review and refine teaching practices and prioritise areas for action and improvement. They [were to] accept responsibility for assessing the impact of their 
teaching on student outcomes and report on and [were to be] accountable for these outcomes. (Department of Employment Education Training and Youth Affairs 2000, p.

\section{1)}

Thus, standards were explicitly linked to student outcomes and to teacher accountability.

Teachers were 'the primary means by which educational standards will be raised' (p. 12).

However, teachers were depicted as needing external assistance to set professional standards. Indeed, standards were to be developed 'by working with and through the teaching profession' (p. 12) in 'a cooperative effort from the Commonwealth Government, State and Territory government and non-government education providers, schools, principals, professional associations and parents' (p. 12). That is, the teaching profession, which included educational leaders, were not granted autonomy to develop standards and determine the norms of professional practice that would lead to improved student outcomes, but rather were to be guided by government.

Within this discourse, school leaders, including teachers in positions of responsibility, were positioned as being one means by which standards could be improved. Indeed leadership and management was the focus of two of the four key elements in the description of the program discussed earlier. The program in Teachers for the 21st Century would develop the skills of school leaders and support quality school management. School leaders were depicted as 'play[ing] a pivotal role in improving student learning' because 'high achieving schools have principals who are effective educational leaders' (Department of Employment Education Training and Youth Affairs 2000, p. 17). That is, quality schooling needed quality leaders to ensure that the quality of teaching was lifted. Leaders would be assisted in this through the program outlined in Teachers for the 21st Century, whose objectives were to 'support school 
principals and their leadership teams to be highly effective educational leaders, people leaders and managers' (Department of Employment Education Training and Youth Affairs 2000, p. 17) and to 'support the development of quality school management' (Department of Employment Education Training and Youth Affairs 2000, p. 18).

Significantly, management featured in both objectives. Management featured also in the following description of effective principals:

they [principals] have a clear vision and high expectations for their schools which they communicate well to the school community; they focus on student achievement and they offer encouragement and support to their teachers. They have a good understanding of the changing nature of schools and teaching and understand the benefits of information communication technologies and lead and manage the changes required to develop children in an online world. While education leadership is the most important part of a principal's job, they also have a key role in managing the school. [emphasis added] (Department of Employment Education Training and Youth Affairs 2000, p. 17-18)

That is, quality leadership was inextricably linked to management.

In turn, quality school management was inextricably linked to student learning outcomes and to teacher quality. The report required 'active management and commitment by school leaders and staff to embrace whole approaches to planning which enables the identification of outcomes and to support staff development to deliver these outcomes' (Department of Employment Education Training and Youth Affairs 2000, p. 14). It planned research that looked at the links between professional development and student learning outcomes. 
Teachers for the 21st Century outlined future programs that would provide support for a 'focus on the professional development of school leaders and whole school management. Research on best practice models of whole school management will be identified and documented' (Department of Employment Education Training and Youth Affairs 2000, p. 18). In this way, Teachers for the 21st Century constructed a discourse on educational leadership that depicted leaders as managers. Quality, or effective, leaders managed school in such a way that teacher quality was lifted and student learning outcomes were improved.

The discourse on standards and quality constructed in Teachers for the 21st Century was characterised by a blaming and shaming of teachers. It used repetition to construct a commonsensical discourse on Australian teachers and schools that led the reader to presuppose as 'true' the low quality of teachers and the need both to improve teacher quality and to raise professional standards (cf. Thomas 2006, for a fuller discussion of presuppositions and truth claims). Despite acknowledging the importance of teachers as the means to achieve this aim, the policy repeatedly categorised teachers as a group that lacked the skills and understandings demanded by the current educational context. It positioned teachers as requiring external assistance in the development of professional standards. Such a positioning is significant as standards set by groups external to the profession are often used as controlling mechanisms (Sachs 2003). Therefore, Teachers for the 21st Century defined quality schooling in terms of the regulation and control of teachers through the development of standards as it constructed a regulatory discourse of quality (Sachs 2003). Within this regulatory discourse, quality leaders were defined not in terms of specific leadership behaviours, but in terms of the means for raising both levels of student outcomes and the quality of teachers. Sachs (2003) described such a discourse as a discourse of quality 
assurance, which justified the development of standards in terms of public accountability. A discourse of quality assurance is a regulatory discourse giving limited professional autonomy to teachers and educational leaders.

\section{Australia's Teachers: Australia's Future}

The second policy that is analysed in this paper was released three years later. Australia's

Teachers: Australia's Future - Advancing Innovation, Science, Technology and

Mathematics (Department of Education Science and Training 2003a) was the final report

of a review implemented

to identify strategies which will increase the number of talented people who are

attracted to teaching as a career, especially in the fields of science, technology and mathematics education, and build a culture of continuous innovation at all levels of

schooling,(Department of Education Science and Training 2003a, p. xiii).

Deleted: Australia's Teachers: Australia's Future constructed a discourse on quality teachers and schools that focused on innovation. Innovation in turn was linked to the economy and to national prosperity.

This discourse was established in the Executive Summary, which stated that sustained innovation is the key to future growth and prosperity in a competitive global economy. Building a culture of continuous innovation through education is an essential requirement, parallel to and supporting research and development. ...

Teachers are the key to mobilising schools for innovation (Department of Education Science and Training 2003a, p. xvii). 
Schooling was inextricably linked to innovation as 'the culture of innovation ... sets directions for the future of schooling. Conversely, and in no small part, that culture of innovation will be a product or outcome of teaching and teachers, of students and their learning' (Department of Education Science and Training 2003a, p. 175). Quality schooling was necessary, therefore, to sustain innovation and was defined in terms of the renewal of cultures of continuous innovation. Unlike Teachers for the $21^{\text {st }}$ Century, quality was not seen to be problematic, although complacency about standards was to be avoided.

Australia has a comprehensive and inclusive education system which performs very well in international comparisons, meeting standards for a well-educated citizenry and workforce. Average standards are high and the best students and schools are amongst the best anywhere, but there is no cause for complacency. (Department of Education Science and Training 2003a, p. xvii)

The report therefore, emphasised not the raising of standards, but the 'energising [of] schools for innovation' (Commonwealth of Australia 2001, p. 217).

The teaching profession would play a leading role in this process. However, Australia's Teachers: Australia's Future noted that the profession needed to be revitalised if it was to meet the increasing challenges of building a culture of innovation in a knowledge economy at the same time as large numbers of experienced, but aging, teachers left the teaching workforce. The focus for this revitalisation was placed on professional learning, which was at the core of upgrading disciplinary and pedagogical knowledge. The development of a national framework for professional learning, for both teachers and educational leaders, was linked to professional standards. Professional standards would provide the means for 'recognising and rewarding teaching excellence and providing opportunities for teachers to 
further develop their expertise and leadership within the profession will aid quality improvement. The profession itself should play a leading role in steps to achieve these outcomes’ (Department of Education Science and Training 2003a, p. xxi).

Educational leaders were identified as being essential to the work on energizing schools for innovation, as the report emphasized the need to work on, among other fronts, 'the role of educational leadership in initiating and steering innovation and change and in directing more autonomous schools' (p. 240). Importantly, leadership was defined as being dependent not on positional authority, nor on age. Rather, it was recognised that leadership could be dispersed and distributed throughout the school community. Leaders were described as people of vision and determination, with the capacity to understand what needs to be changed or strengthened and the ability to move things forward. So leaders are innovators themselves or they support innovation in others. ... [they] support[s] student and teacher initiatives by allowing exploration of new ideas. (p. 221) As such, leaders envisioned goals, affirmed values, motivated, managed, explained and served as a symbol or model. Management was seen to be but one aspect of leadership, which also included behaviours such as fostering shared meanings, connectivity for service and the valuing of people.

Further, support was heavily emphasised in this discourse on quality leadership. Once again, the discourse focused on specific behaviours, noting that a 'strong and supportive school leadership’ (p. 36) of the 'highest order able to provide the direction, encouragement and support required to reach agreed educational goals and targets' (p. 178) was a powerful instrument for building the capabilities and resourcefulness of schooling. In particular, 
leaders needed to support learning by giving very positive messages, showing knowledge of the value of specific learning areas, and ensuring a positive school climate. 'Learning ... thrives when supported by clear minded and firm leadership' (p. 34). Thus, successful schools depended on 'effective leadership and the energies and goodwill of teachers, students and communities' (p. 179)

In this way, Australia's Teachers: Australia's Future shifted from the culture of blaming and shaming that characterised Teachers for the 21st Century as it constructed an alternative discourse on quality. The discourse constructed in Australia's Teachers: Australia's Future defined quality in terms of enhanced teacher professionalism, not one of merely lifting the standards of teachers or of student outcomes. Unlike Teachers for the 21st Century, the discourses constructed in Australia's Teachers: Australia's Future moved from an emphasis on blaming teachers for low quality schooling to portraying them as the resource for change. Similarly, it moved from one of regulation and control to one of professional development, which was defined in terms of professional learning, and the revitalisation of the teaching profession. Teachers were charged with taking responsibility for their professional learning, not subject to the development of standards by external bodies. Rather than defining leadership in terms of student outcomes and the management and quality of teachers, the discourse on leaders constructed in Australia's Teachers: Australia's Future defined leadership in terms of specific behaviours that encouraged the valuing of, and support for, both people and professional learning.

Such a discourse is best described as a discourse of quality improvement through standards (Sachs 2003) as it takes a developmental approach to standards in the context of teacher 
professional development, learning and career advancement. The development of standards is seen as a means of making explicit the norms of professional practice to which pupils are entitled and of which the wider public has a legitimate right to be assured. The adoption of such an approach leads to transparency regarding the social and professional expectations and obligations of teachers. Professional standards developed in this context signal a democratic form of professionalism (Ingvarson 1998) and are most likely to be in the best interests of the profession (Sachs 2003)

\section{Policy Discourses, Standards and Leadership}

Thus, it can be seen that both policy discourses traced above emphasised the importance of professional standards and the role of educational leaders in their development. However, each discourse advocated the development of standards through different means and for different purposes. The discourse that was constructed in Teachers for the $21^{\text {st }}$ Century linked standards to the improved accountability of both teachers and educational leaders as a means of lifting student outcomes. Further, leaders were depicted as managers, responsible for improving teacher quality. It was a discourse of quality assurance, one that emphasised regulation and certification through standards. The discourse constructed in Australia's Teachers Australia's Future was a discourse of quality improvement, emphasising the role of standards in teacher development through professional learning. Leaders are depicted in this discourse as the leaders of a learning profession, leading and supporting teachers in their professional development and in the energising of schools for innovation. However, it is important to note that elements of both discourses, that is of a regulatory discourse of quality assurance, and of a developmental discourse of quality improvement, can be traced in both 
policy documents.

For example, although predominantly an advocate of regulation through certification, Teachers for the $21^{\text {st }}$ Century notes that the development of standards requires 'teachers taking responsibility for their professional development and for using its outcomes to improve their teaching and their students' learning' (Department of Employment Education Training and Youth Affairs 2000, p. 14). That is, it acknowledges the importance of teachers both to the development of professional standards and to the raising of educational standards as the following quote demonstrates.

Raising the standards of student performance is an on-going task, not just for teachers but for the community as a whole. It requires cooperative effort from the Commonwealth Government, State and Territory government and non-government education providers, schools, principals, professional associations and parents. But the primary means by which educational standards will be raised will be by working with and through the teaching profession. (Department of Employment Education Training and Youth Affairs 2000, p. 12).

Similarly, while best described as constructing a discourse of quality improvement, Australia's Teachers Australia's Future suggests elements of a discourse of quality assurance when it notes that 'professional standards will provide a basis of competence for all teachers. ... They will also improve the public profile and standing of the teaching profession' (Department of Education Science and Training 2003a, p. xxi).

That both policy documents contained elements of both discourses on standards, while favouring one discourse over the other, can be explained by an understanding the education 
policy-making process as a site of competing discourses in hegemonic struggles over education (Thomas 2006). In such struggles, commonsense understandings of education are naturalised through the construction of a preferred discourse on education. In the policy documents analysed above, each policy constructed a preferred discourse that legitimated certain understandings of quality and standards, of what it means to be a good teacher and a good leader, at the expense of others. However, the presence of alternative discourses in these policies indicated ambiguities and contradictions that offer spaces for contestations over these commonsense understandings that may lead to new ways of thinking about quality teachers and leadership.

\section{Leadership in Policies for Quality}

The critical discourse analysis of the two policies outlined above has traced how quality, and thus educational leadership, was discursively constructed within the Australian quality policy context. That is, it showed how the professional identity of educational leaders was shaped and constrained within a discursive field constructed through discourses on policy. Further, it demonstrated how policies for quality construct multiple, sometimes contradictory discourses on professional standards. In particular, it showed how two recent policies for quality constructed preferred discourses on quality and standards, both of which emphasised the importance of leadership. One discourse was a regulatory discourse of quality assurance in which leaders were positioned on the one hand as needing to improve skills, and on the other as necessary to the management and regulation of teachers. The second discourse was a discourse of quality improvement that positioned leaders as a key to reinvigorating the teaching profession through the leading and of, and support for, professional learning. 
Elements of both discourses were traced in both policies, indicating ambiguities and contradictions that opened up spaces for questioning commonsense understandings of leadership practices. Such questions included understanding of ideas of leadership as opposed to management; of a supportive leader as opposed to a regulator of teachers; and of leading for professional learning as opposed to regulating for improved student outcomes.

In conclusion, this paper has investigated the discursive construction of leadership in the Australian quality policy context. It showed how the role and sense of school leaders are being reworked and redefined in struggles over language, policy and practice. In so doing, it raised questions about how leadership should be rethought in the context of policy discourses for quality. More investigations are needed into how leaders respond to these questions into these shifting discourses of leadership. Such investigations need to focus on the shifting and complex positioning of real people or institutions and their roles in specific places and over specific periods of time. In particular, investigations are needed, into how they position themselves through alternative discourses as such positioning may lead to new ways of thinking about, and doing, leadership. 


\section{Endnotes}

1. The Commonwealth of Australia is made up of six states and two territories. Under the Australian constitution, each of the State Governments has responsibility for the provision of school education in that state. However, the national, or Commonwealth, Government wields considerable influence over education policies through the judicial allocation of funding raised through taxes. This paper refers to education policies for quality in both the general Australian education context and in the specific context of the State of Queensland. 
References

Allan, S. (1998) News from Nowhere: Televisual News Discourse and the Construction of Hegemony, in: A. Bell and P. Garrett Approaches to Media Discourse (Oxford: Blackwell Publishers), 105-141.

Apple, M. W. (1989) Critical Introduction: Ideology and the State in Education Policy, in: R. Dale The State and Education Policy (Milton Keynes: Open University Press), 1-20.

Apple, M. W. (1996) Power, Meaning and Identity: critical sociology of education in the United States, British Journal of Education, 17(2), 125-144.

Apple, M. W. (2001) Markets, standards, teaching, and teacher education, Journal of Teacher Education, 52(1), 182-196.

Apple, M. W. (2004) Ideology and the Curriculum (New York and London: Routledge Falmer).

Ball, S. J. (1993) What is Policy? Texts, Trajectories and Toolboxes, Discourse: The Australian Journal of Educational Studies, 13(2), 10-17.

Ball, S. J. (1994) Education Reform A critical and post-structural approach (Buckingham: Open University Press).

Bell, L. and Rowley, A. (2002) The impact of educational policy on headship in primary schools in England, 1994-2001, Journal of Educational Administration, 40(2/3), 195210.

Board of Teacher Registration (1987) Project 21: Teachers for the Twenty-First Century (Toowong: Board of Teacher Registration).

Chouliaraki, L. and Fairclough, N. (1999) Discourse in Late Modernity Rethinking Critical Discourse Analysis (Edinburgh: Edinburgh University Press). 
Collard, J. (2004) Learners, Initiators, Servants: The Self-Images of Victorian Principals in the 1990s, The Australian Educational Researcher, 31(1), 37-56.

Commonwealth of Australia (2001) Backing Australia's Ability An Innovation Action Plan for the Future (Fyshwick, ACT: Paragon Printers Australasia).

Dawkins, J. (1988) Strengthening Australia's Schools (Canberra: Australian Government Publishing Service).

Department for Education and Employment (2001) schools* building on success raising standards, promoting diversity, achieving results (Norwich: DfEE).

Department of Education Science and Training. (2003a) Australia's Teachers: Australia's Future Advancing Innovation, Science, Technology and Mathematics. Available online at http://dest.gov.au/schools/teachingreview/documents/Main-Report.pdf (accessed 19 September 2004.

Department of Education Science and Training. (2003b) National Quality Schooling Framework. Available online at http://www.dest.gov.au/schools/publications/2003/NQSF/Brochure.pdf (accessed 9 December 2003.

Department of Employment Education Training and Youth Affairs (2000) Teachers for the 21st Century: Making the Difference (Canberra: Commonwealth of Australia).

Education Queensland. (1999) Queensland State Education 2010 (QSE - 2010). Available online at http://education.qld.gov.au/corporate/qse2010/pdf/strategy.pdf (accessed 30 August 2004.

Fairclough, N. (1989) Language and Power (London: Longman).

Fairclough, N. (2001) Language and Power second edition (Harlow, England: Longman). Fairclough, N. (2003) Analysing Discourse and Text: Textual Analysis for Social Research 
(London: Routledge).

Grace, G. (2000) Research and the challenges of contemporary school leadership: The contribution of critical scholarship, British Journal of Educational Studies, 48(3), 231-247.

Gunter, H. (2001) Critical approaches to leadership in education, Journal of Educational Enquiry, 2(2), 94-108.

Harvey, D. (1996) Justice, Nature \& the Geography of Difference (Oxford: Blackwell Publishers).

Henry, M., Lingard, B., Rizvi, F. and Taylor, S. (2001) The OECD, Globalisation and Education Policy (Oxford, UK: IAU Press).

Higgins, C. (1991) Broadcast news: a linguistic mode of analysis, Continuum: The Australian Journal of Media and Culture, 5(1), 149-165.

Ingvarson, L. (1998) Teaching standards: foundations for professional development reform, in: A. Hargreaves, A. Lieberman, M. Fullan and D. Hopkins International Handbook of Educational Change (Amsterdam: Kluwer).

Kress, G. and van Leeuwen, T. (1996) Reading Images: The Grammar of Visual Design (London: Routledge).

Luke, A. (2002) Beyond Science and Ideology Critique: Developments in Critical Discourse Analysis, Annual Review of Applied Linguistics, 22, 96-110.

Maclure, M. (1994) Language and Discourse: the embrace of uncertainty, British Journal of Sociology of Education, 15(2), 283-300.

Ministry of Education (1998) Teacher Performance Management (Wellington: Ministry of Education).

National Project on the Quality of Teaching and Learning (1992) National Project on the 
Quality of Teaching and Learning (Canberra, A.C.T.: National Board of Employment, Education and Training).

Olson, L. (2000) Policy focus converges on leadership Education Week, 19(17), 1-3.

Peters, M., Marshall, J. and Fitzsimons, P. (2000) Managerialism and Educational Policy in a Global Context: Foucault, Neoliberalism, and the Doctrine of Self-Management, in:

N. C. Burbules and C. A. Torres education and globalization critical perspectives

(New York: Routledge), 100-132.

Quality of Education Review Committee (1985) Quality of Schools in Australia (Canberra: A.G.P.S.).

Ramsey, G. (2000) Quality Matters Revitalising teaching: Critical times, critical choices Report of the Review of Teacher Education, New South Wales (Sydney: NSW Department of Education and Training).

Ribbins, P. and Gunter, H. (2002) Mapping leadership studies in education: Towards a typology of knowledge domains, Educational Management \& Administration, 30(4), 359-385.

Sachs, J. (2003) The Activist Teaching Profession (Buckingham: Open University Press). Schools Council (1990) Australia's Teachers An Agenda for the Next Decade (Canberra: Australian Government Publishing Service).

Schram, S. F. (1993) Postmodern policy analysis: Discourse and identity in welfare policy, Policy Sciences, 26, 249-270.

Senate Employment Education and Training References Committee (1998) A Class Act Inquiry into the Status of the Teaching Profession (Canberra: Commonwealth of Australia).

Smith, D. E. (1990) Texts, Facts, and Femininity (London: Routledge). 
Spillane, J. P., Halverson, R. and Diamond, J. B. (2004) Towards a theory of leadership practice: a distributed perspective, Journal of Curriculum Studies, 36(1), 3-34.

Taylor, S. (2004) Researching educational policy and change in 'new times': using critical discourse analysis, Journal of Education Policy, 19(4), 433-451.

Thomas, S. (2004) Initial investigations into the interrelationships between Policy, Leadership and Governance Discourses in Educational Sites, in: B. Bartlett, F. Bryer and D. Roebuck 2nd Annual International Conference On Cognition, Language And Special Education Research ( Crowne Plaza Surfers Paradise, Gold Coast, Queensland, Australia), 165-176.

Thomas, S. (2005) The construction of teacher identities in educational policy documents: a Critical Discourse Analysis, Melbourne Studies in Education, 46(1), 25-44.

Thomas, S. (2006) Education Policy in the Media: Public Discourses on Education (Teneriffe: Post Pressed).

Thomson, P. (2003) No more managers-r-us! Researching/teaching about head teachers and schools in challenging circumstances', Journal of Education Policy, 1(3), 333-346.

Vidovich, L. and Porter, P. (1999) Quality policy in Australian higher education of the 1990s: university perspectives, Journal of Education Policy, 14(6), 567-586.

Whitty, G. (2002) Making Sense of Policy (London: Paul Chapman Publishing). 